\title{
Sardine canning by-products as sources of functional ingredients
}

Ana P. Carvalho ${ }^{\dagger *}$, Manuela Amorim ${ }^{\dagger}$, Luís Rodríguez-Alcalá ${ }^{\dagger ‡}$, Javier Fontecha ${ }^{\ddagger}$, Paula M. L. Castro $^{\dagger}$, Manuela E. Pintado ${ }^{\dagger}$

${ }^{\dagger}$ CBQF - Centro de Biotecnologia e Química Fina - Laboratório Associado, Escola Superior de Biotecnologia, Universidade Católica Portuguesa/Porto, Rua Arquiteto Lobão Vital, Apartado 2511, 4202-401 Porto, Portugal

${ }^{\ddagger}$ REQUIMTE/LAQV, Instituto Superior de Engenharia, Porto Polytechnic Institute, Rua Dr. António Bernardino de Almeida, 4249-015 Porto, Portugal

$\S$ Centro de Investigación en Recursos Naturales y Sustentabilidad (CIRENYS), Universidad Bernardo O'Higgins, Avenida Viel 1497, Santiago de Chile, Chile

* Bioactivity and Food Analysis Department, Food Lipid Biomarkers and Health Group, Institute of Food Science Research (CIAL, CSIC-UAM), C/Nicolás Cabrera 9, Madrid28049, Spain

* Corresponding author: Ana P. Carvalho, ana.carvalho@graq.isep.ipp.pt; ana.p.santos.carvalho@gmail.com 


\begin{abstract}
Sardine by-products generated during canning process entail a potential opportunity to drive them into a chain of high added-value compounds, while simultaneously decreasing the environmental impact of their discharge. This paper describes and discusses the biochemical variation of solid and liquid by-products generated during the canning process of sardine along one complete year. Additionally, by-products were also evaluated in terms of their degradation along time, monitored through microbiological and chemical analysis. Finally, their valorisation was ascertained through the recovery of lipid fractions rich in $\omega 3$ polyunsaturated fatty acids (PUFA), as well as protein fractions with anti-hypertensive activity (ACE). The variability within biochemical composition of by-products along the year is significant, especially in terms of lipid content, and their degradation is strongly dependent on the conditions in which they were collected and stored. Both liquid and solid by-products present $\omega 6 / \omega 3$ ratios between $0.05-0.18$ and thrombogenic index between 0.27-0.57, whereas low-molecular-weight fractions of protein extracts $(<3 \mathrm{kDa})$ exhibited the strongest $\mathrm{ACE}$ activity $\left(\mathrm{IC}_{50}=51 \mu \mathrm{g} / \mathrm{ml}\right)$. The potential viability of using liquid by-products as sources of functional ingredients is an interesting alternative to the management of these effluents in fish canning industry.
\end{abstract}

Keywords: fish canning industry; food wastes; by-products valorisation; bioactive compounds; $\omega 3$ PUFA; microbial degradation; lipid oxidation 


\section{Introduction}

The amount of by-products generated by fish processing industry in EU represents ca. 5.2 million tonnes/year, from which 30-65\% account from fish canning industry. ${ }^{1}$ Globally, fish processing industries generate substantial amounts of solid and liquid wastes, that present considerable disposal problems, and therefore are an issue with increasing importance. Furthermore, considering the state of collapse of fish stocks and marine habitats and the increase in per capita consumption of fish, there is a growing interest in an intelligent management of resources, achieved by reusing fish by-products or discards. ${ }^{2}$ There is a multitude of discards obtained from fish processing, which can lead to the production of various products. For example, fish skin may be used to the production of collagen and gelatine, to be applied in pharmaceutical, cosmetic and food industries, whereas scales and bones are interesting sources of hydroxyapatite, with potential applications in biomaterial industry. Discards rich in organic compounds (e.g. viscera, heads, tails, flesh residues and specific wastewaters) are rich in proteins and lipids, including proteolytic enzymes, bioactive peptides and long-chain $\omega 3$ polyunsaturated fatty acids (PUFA), which can be used as ingredients in food industry. ${ }^{3-6}$ The abovementioned discards (either solid or liquid) are generated during the various steps of canning process, briefly described below, and depicted in Figure S1.

Canning fish processing starts with the reception of fish, either refrigerated or frozen, and goes through various steps of brining, removal of unwanted parts, (steam) drying, eventual removal of additional unwanted parts, canning, sterilization and packing. ${ }^{3}$ The various washing steps performed along the process result in a large volume of wastewaters, rich in organic compounds, typically of $15 \mathrm{~m}^{3} /$ ton of processed fish (unpublished results). Apart from those liquid discards, considerable amounts of solid discards are also produced (from heads, skins, scales, bones, discards from filleting, as well as viscera), which may range $350-400 \mathrm{~kg} / \mathrm{ton}$ of processed fresh or frozen fish. ${ }^{7}$

In a logical of life-cycle assessment, those solid and liquid outputs are usually classified as waste products (which provide little or no revenue), as their revenue is, respectively, nil or very low ${ }^{8}$ (solids are usually sold for fishmeal at ca. $0.03 € / \mathrm{kg}$ ). Besides, such economic considerations do not account for the costs related with the handling of those discards, namely the liquids, as they are not allowed to be discharged directly through the municipal sewage system, due to their high amounts of organic loads. Therefore, they require an extra treatment step, which is obligatory and 
costly to the companies. However, their redirection to valorisation, in order to obtain new addedvalue products or ingredients, may become economically more interesting than the treatments for discard applied at the end of the line.

Despite the large number of studies concerning alternative applications for fish processing byproducts, very few value-added compounds showed economic profitability to reach the market. Olsen et al. (2014) ${ }^{9}$ pointed out the overestimation of market possibilities, lack of enough (and regular) amounts of high quality by-products available, and high costs of isolating specific components, as possible explanations. One potential solution to overcome those limitations relies on the recovery of bioactive compounds with already existent (and highly-priced) market, such as the abovementioned lipids rich in $\omega 3$ PUFA.

Although there is are large number of studies focused on the valorisation of solid fish byproducts $^{5-7,10-11}$, the potential exploitation of liquid fractions has been scarcely undertaken so far. Additionally, most of the studies published concern the use of by-products collected in only one sampling time, which leads to unrealistic conclusions regarding regular productivity, because the composition of fish (especially fatty fish) is extremely variable around the year. In order to shed light into these two parameters, the present study aimed to characterize the composition of liquid by-products from sardine, a fatty fish widely consumed in the North of Portugal and Galicia, along one complete year. By characterizing several types of liquid by-products, collected in different steps of the production process, the present study provides the necessary information to select the richest wastewaters (in valuable organic compounds) to work with, instead of a mixture with the whole volume of wastewaters generated, since the valorization of specific parts is economically more feasible than the use of the whole amount. Solid discards were also studied in this work, although in fewer sampling periods, as a complementary and comparative analysis. Simultaneously, the degree of decomposition was ascertained through microbiological and chemical (oxidation) analysis, which are parameters rarely published, although of utmost importance to assess the viability of recovering by-product matrices. Finally, the potential valorisation of lipid and protein fractions was evaluated targeting the production of $\omega 3$ PUFA and extracts with anti-hypertensive activity, respectively. The potential viability of using liquid byproducts as sources of functional ingredients may be an innovative approach to the management of these effluents in fish canning industry. 


\section{Materials and Methods}

Samples

By-products analysed consisted on solid (a mixture of heads and cooked skins) and liquid samples from sardine (Sardina pilchardus), collected in several periods of time in Poveira Company, located in the North of Portugal (Póvoa de Varzim). Concerning the liquid samples, they were collected from brining step, washing step (mixture of the effluent from the several washing steps along the process), and three liquid discards from the drying step. During steam drying, fish is placed (in metal trays) inside the steam cooker equipment, where it is partially dried by steam at $100^{\circ} \mathrm{C}$. Steam driers allow the simultaneous entry of steam and drainage of condensate to a lateral reservoir, connected to the main drain liquid effluent piping. Discards from the drying step were collected from the lateral reservoir of the equipment, from the main drain liquid effluent piping, and from the bottom of the trays that are placed with the fish inside the drying equipment - detail in Figure S1.

In a first approach, all the liquid residues were analysed, in order to evaluate their valorisation potential; afterwards, those liquid matrices presenting higher content of proteins and/or lipids were selected for study over one year. Liquid samples selected were collected during 4 different periods of time: April, July and December (year 1), and one year after the starting, i.e., in May of the year 2. This sampling procedure made it possible to assess the biochemical variability along one complete year, as well as the variability for the same season within two consecutive years. Solid samples were only collected in two different periods of time (December of the year 1 and May of the year 2). After sampling, residues were immediately transported in refrigerated boxes and frozen in no more than 2 hours, being thawed before analysis. The only exception was for degradation analysis, performed with fresh samples. All the abovementioned samplings were always collected in triplicate.

\section{Biochemical characterization}

Triplicates of samples were characterized in terms of total protein (Kjeldahl, ISO R 973:1978), total lipid (Soxhlet, AOAC 960.39), ash (AOAC 999.07) and dry matter content (EN $12880.2000) 6^{12-14}$.

\section{$\underline{\text { Degradation analysis }}$}


Evolution of microbial and chemical degradation along time was monitored through the determination of microbial load and oxidation degree, respectively. The former was quantified by the counting of total coliforms at $30^{\circ} \mathrm{C}(\mathrm{NP} 3788: 1990)^{15}$, whereas the later consisted in the determination of peroxides (ISO 3960:2007) ${ }^{16}$ and $p$-anisidine (AOCS Cd 18-90) ${ }^{17}$ values. These analyses (in triplicate) were performed in fresh samples from December and May. In order to evaluate the effect of freezing in the degradation rates, the samples from May were frozen during 3 months and subsequently re-analyzed (samples coded as August, year 2).

\section{Evaluation of added-value components}

\section{Sample preparation}

In a preliminary step, solid by-products (cooked skins and heads) were homogenized in a benchscale homogenizer and mixed with water at proportions of 1:2(w/v), whereas liquid by-products (from the bottom of the trays that are placed with the fish inside the drying equipment) were processed as they arrived. Both types of by-products were then submitted to a process of solvent extraction and centrifugation in controlled optimized conditions, in order to separate the richprotein (hydrophilic) and lipid (hydrophobic) fractions. These two procedures are detailed in the following sections and depicted in Figure 1.

\section{Quantification of $\omega 3$ fatty acids in lipid fractions}

Lipid extraction was performed with hexane, ${ }^{18}$ and phase separation was performed in a refrigerated ultracentrifuge (JOUAN MR1822). Subsequently, the lipid fraction was submitted to evaporation under reduced pressure, in order to remove the solvent and enable its reuse. Afterwards, lipids were quantified gravimetrically and analysed in terms of fatty acid profile, so as to ascertain their contents in $\omega 3$ fatty acids, following the procedure described in CastroGómez et al. (2014). ${ }^{19}$ All analyses were carried out at least in duplicate. In these conditions the limit of detection (LOD) was $0.009 \mu \mathrm{g} / \mathrm{mL}$ and the limit of quantification (LOQ) was 0.03 $\mu \mathrm{g} / \mathrm{mL}$. 


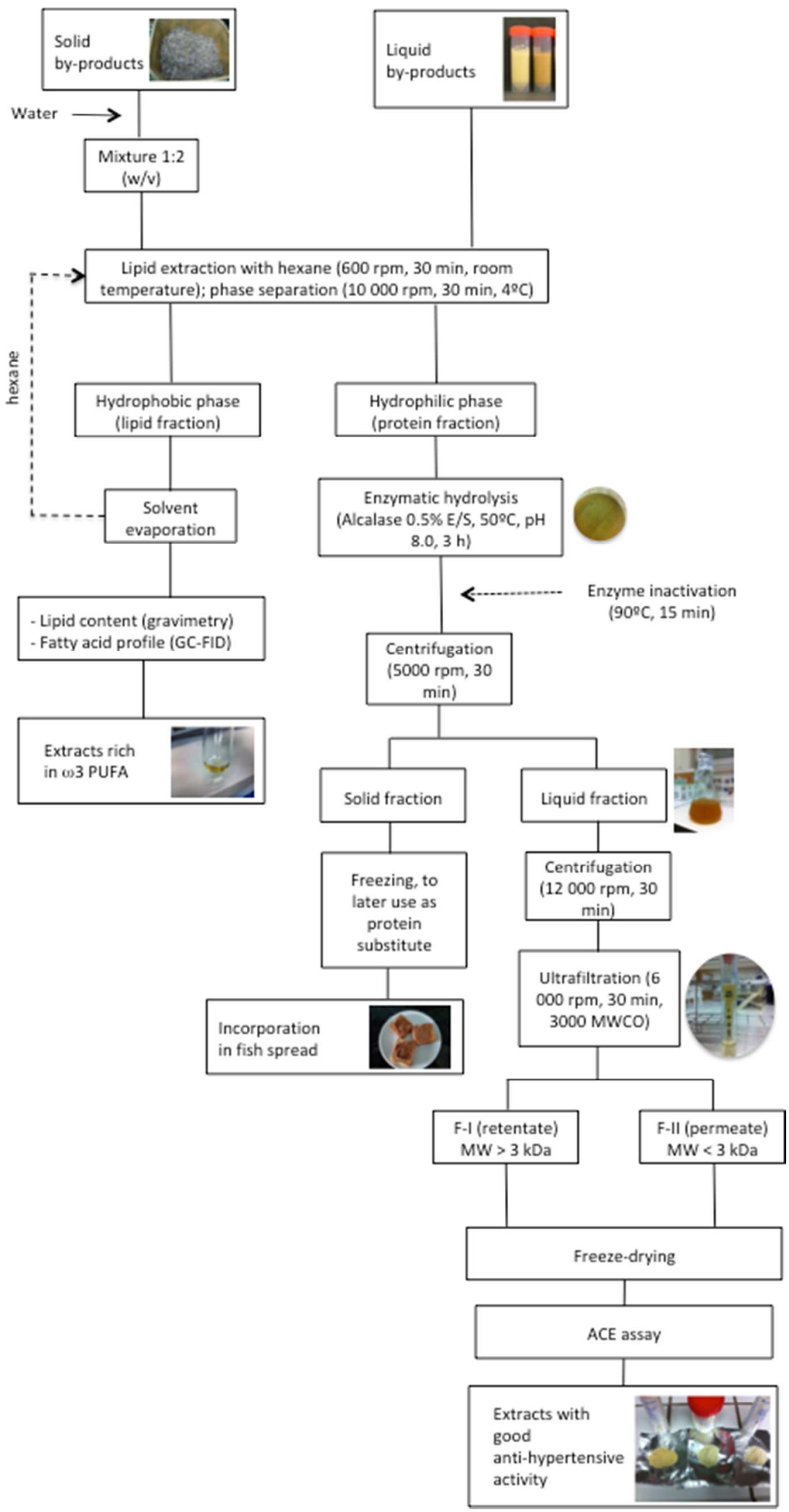


Figure 1 - Valorisation scheme of liquid (L3 - from the bottom of the trays that are placed with the fish inside the drying equipment) and solid (heads and cooked skins) by-products

Enzymatic hydrolysis and quantification of anti-hypertensive activity (ACE) in protein fraction The hydrophilic fractions (i.e. the remaining solids and water, after lipid separation) were hydrolysed, and the separation of fractions by molecular weight (MW) was achieved through membrane ultrafiltration. The process was designed as described in Figure 1: the fractions were submitted to an enzymatic hydrolysis with Alcalase at 0.5\% (E/S) (Alcalase 2.4G, Novozymes). After enzyme inactivation, the fraction was centrifuged, and two fractions could be obtained: (i) the solid fraction, which was used as protein substitute in fish spread; and (ii) the liquid fraction, which was submitted to another centrifugation step and ultrafiltration with Centrifugal Filter Units 3000 MWCO (Millipore). The resulting fractions of this ultrafiltration step (F-I and F-II, representing the fractions with MW distribution of $>3 \mathrm{kDa}$ and $<3 \mathrm{kDa}$, respectively) were recovered and freeze-dried. Both protein fractions were then diluted in ultrapure water and tested for anti-hypertensive activity (ACE assay) according to the procedure previously described in Tavares et al. (2011). ${ }^{20}$ Hydrolysis degree was calculated according to the $\mathrm{pH}$-stat method (Dumay et al. 2009). ${ }^{21}$

\section{$\underline{\text { Statistical analysis }}$}

Analysis of variance (ANOVA) and Tukey or Games-Howell post-hoc tests were used to analyse the results, using IBM ${ }^{\circledR}$ SPSS ${ }^{\circledR} 22$ Statistics software for Windows (SPSS Inc., Chicago, IL, USA). Differences were considered significant when $p<0.05$.

\section{Results and Discussion}

Biochemical composition and seasonal variation of solid and liquid sardine by-products

In order to reduce the number of by-product matrices to characterize over one year, wastewaters from various steps of canning processing (brining, washing and drying) were firstly evaluated in terms of biochemical composition. As previously mentioned, three liquid discards from the drying step were collected: from the lateral reservoir of the equipment, from the main drain liquid effluent piping, and from the bottom of the trays that are placed with the fish inside the drying equipment. Results are depicted in Figure 2, where it can be observed that wastewaters from brining and washing processes present the lowest amounts of organic content (protein and lipids), 
and were therefore discarded. The low amount of organic content in the wastewaters from washing step may be explained because of their large dilution, since washing step effluents were a mixture of the effluent from the several washing steps along the process.

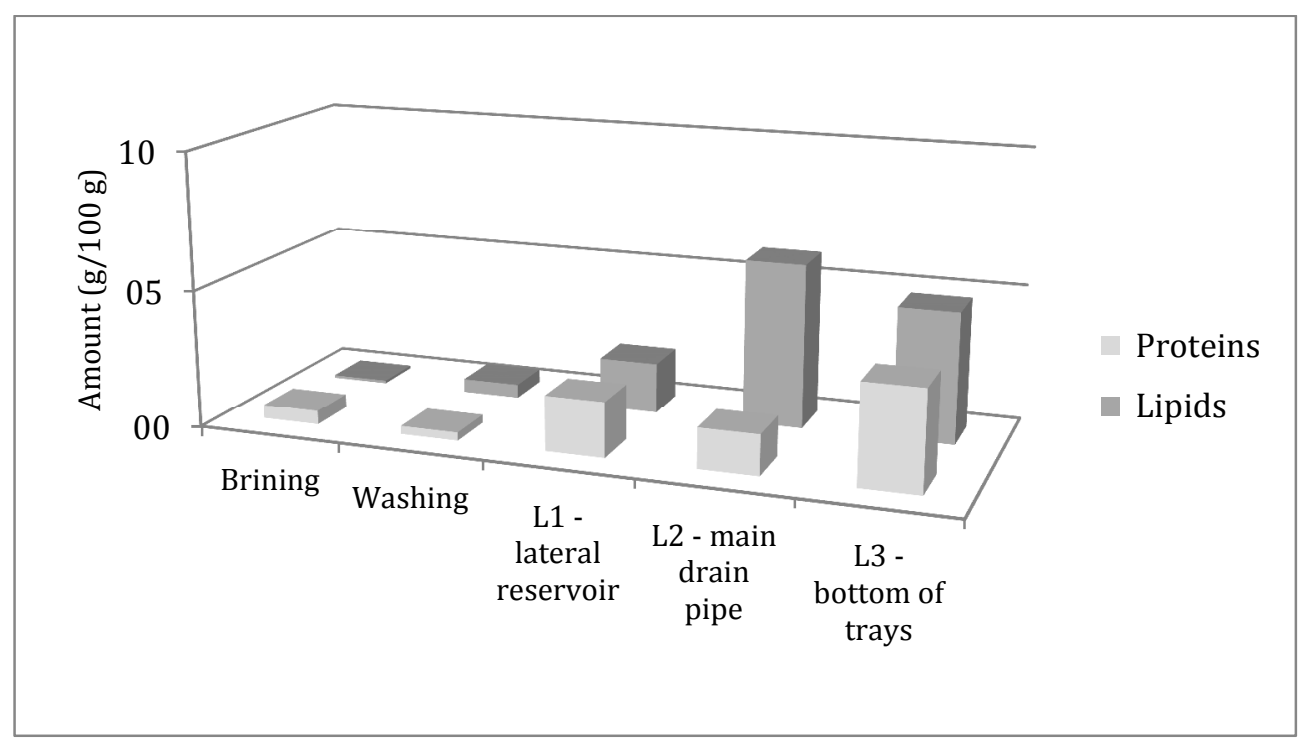

Figure 2 - Biochemical composition in liquid discards collected from several steps along the processing plant: brining step, washing step (mixture of the effluent from the several washing steps along the process), and three liquid discards from the drying step (L1 - collected from the lateral reservoir of the equipment, L2 - from the main drain liquid effluent piping, and L3 - from the bottom of the trays that are placed, with the fish, inside the drying equipment)

Thus, pre-selected liquid by-products were only those from drying step, as they simultaneously present the higher potential for valorisation and higher environmental impact. Among these, those wastewaters arising from the main drain liquid effluent piping were also discarded, due to the high oxidation values presented (data not shown).

Since most canning companies process fish all over the year, significant differences in biochemical composition are expected. Therefore, any reliable evaluation of the potential of valorisation of by-products must take this factor into account, and biochemical composition should be an average of the yearly variation. Results of the biochemical composition of liquid byproducts along one-year cycle (from April to May), as well as of solid by-products along two sampling periods, are presented in Figure 3.

Regarding liquid by-products, results for total protein and lipids are depicted in figure $3 \mathrm{~A}$ for wastewater from the lateral reservoir (L1) and in figure 3B for wastewater from the bottom of the trays (L3). Analysis of those figures reveals that the total amounts of lipids and proteins are 
higher for L3, although varying during the year; lowest values were reached in the sampling of December. Additionally, both liquid by-products present similar (although statistically different) values of total protein along the year, but large variations among lipid values, with higher amounts in July and May. In fact, the lipid content of sardine meat has been reported to vary between $1-15 \%$, according to the capture season. ${ }^{22}$ Sardine life cycle comprises a peak of spawning, which usually occurs near February, the time of year when sardine is thinner. Sardine gradually gets fatter, more or less rapidly according to the environmental conditions. In conclusion, the large variability in biochemical composition among samplings suggests the need to use annual average values to assess the total quantity of lipids and proteins capable of be recovered from these by-products.

Average protein amount was not markedly different between the two sampling points of liquid by-products (L1: $2.4 \mathrm{~g} / 100 \mathrm{~g}$ of by-products, and L3: $2.8 \mathrm{~g} / 100 \mathrm{~g}$ of by-products), but lipid amount was significantly different (L1: $3.5 \mathrm{~g} / 100 \mathrm{~g}$, and L3: $30.8 \mathrm{~g} / 100 \mathrm{~g}$ ). The comparative analysis of these values is rather difficult due to the absence of published results regarding liquid by-products from fish canning industry. One of the few studies found on the recovery of lipids in tuna cooking effluents at $70^{\circ} \mathrm{C}$, reporting amounts of $2 \mathrm{~g}$ lipids $\mathrm{L}^{-1} .^{23}$

The characterization of solid by-products (skins and heads) is presented in Figure 3C. From analysis of results it can also be observed the statistically significant variability in results along the year, already referred to liquid samples. The amounts of proteins in those solid by-products are consistently higher than those found in liquid by-products, and are also higher in skins when compared with heads. Average values range from 17 and $21 \mathrm{~g}$ protein/100 $\mathrm{g}$ for heads and skins, respectively, and 16 and $20 \mathrm{~g} \mathrm{lipid} / 100 \mathrm{~g}$ of heads and skins, being comparable with those reported by other authors. Indeed, Batista et al. ${ }^{24}$ reported amounts of raw and cooked byproducts from Sardina pilchardus (heads, viscera, frames and trimmings) ranging between 13-14 $\mathrm{g}$ protein $/ 100 \mathrm{~g}$ and 14-15 g lipid/100 g, whereas Dumay et al. ${ }^{25}$ indicated lower values $(4.9 \mathrm{~g}$ lipid/100 g and $15.8 \mathrm{~g}$ protein /100 g) for S. pilchardus viscera caught between April and June. Although the total amounts of protein are higher in solid by-products than in their liquid counterparts, such statement is not valid for lipid amounts, since those arising from L3 wastewater present average higher values of lipid content. Thus, it might be worthwhile to consider the possibility to recover liquid by-products in canning industries, provided they are only from specific sampling spots (e.g. L3). 


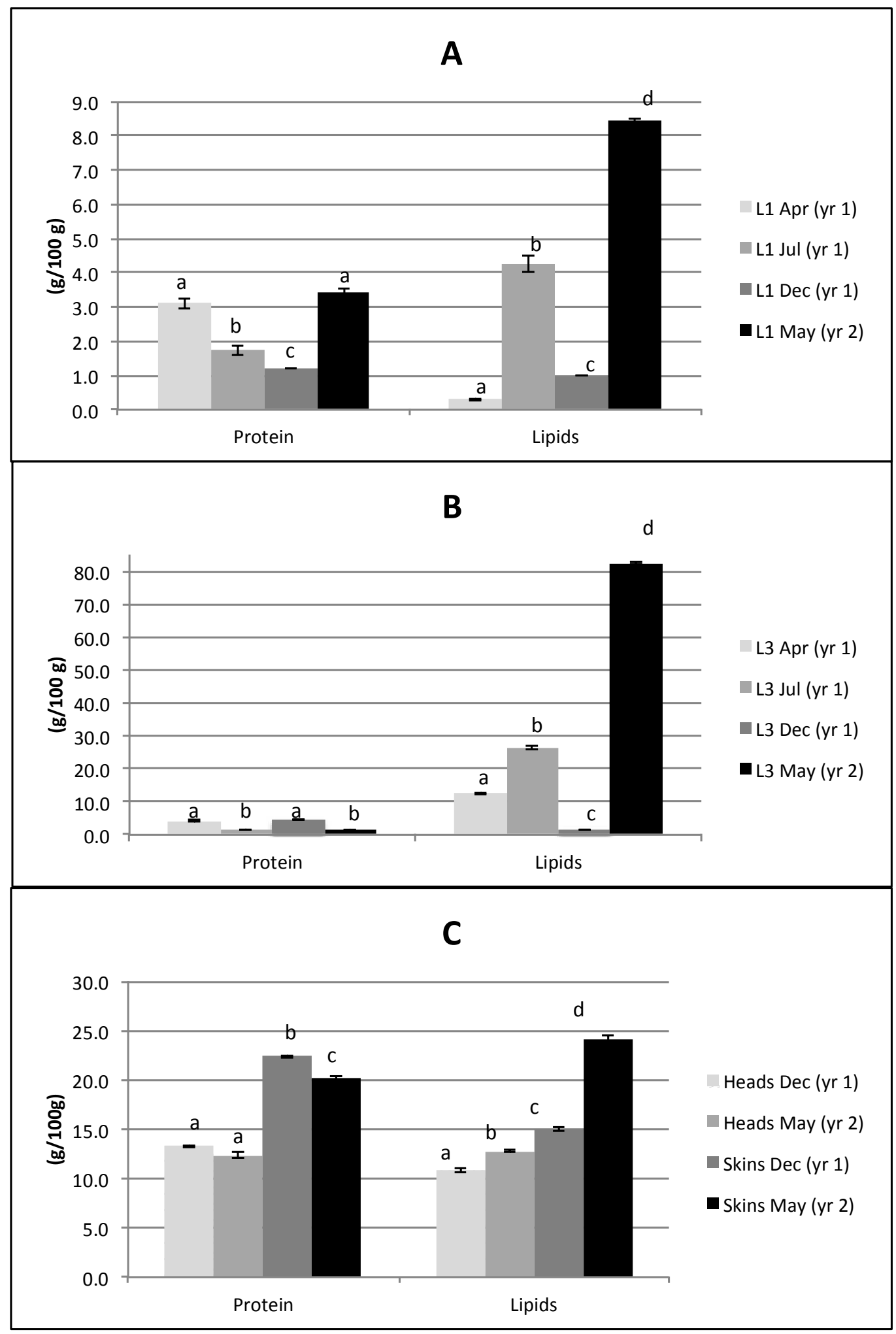


Figure 3 - Biochemical composition of liquid and solid discards. Liquid discards are from drying step, collected in different locations and through the four sampling points of the year (April, June and December from year 1, and May of year 2). A: L1 - wastewaters collected from the lateral reservoir of the drying equipment; B: L3 - wastewaters collected from the bottom of the metal trays where the fish is placed to go inside the dryers. C: Solid discards (heads and cooked skins) are collected along two sampling points of the year (December of year 1 and May of year 2). Values with different letters are significantly different.

\section{Evaluation of the degree of degradation}

Following biochemical characterization, a study of maintenance/depreciation of by-products collected was initiated, so as to assess their susceptibility to microbial contamination and oxidation. To this end, a monitoring of the evolution of the degree of degradation over time, by determining levels of lipid oxidation and microbial load was performed.

Peroxide (PV) and $p$-anisidine (AV) values are reliable methods for rancidity measurement: high PV indicates formation of hydroperoxides (primary oxidation compounds), whereas AV is studied to assess secondary lipid oxidation development due to the presence of secondary products (carbonyl compounds). ${ }^{26}$ Crude fish oil quality guidelines indicate that peroxide value and $p$-anisidine number should range between 3-20 meq $\mathrm{O}_{2} / \mathrm{kg}$ fat and 4-60, respectively. ${ }^{27}$ Results concerning lipid oxidation are presented in Figure 4. Peroxide values are always higher than the limits, both for liquid (A) and solid (B) samples, for all the sampling periods. $P$-anisidine values also exceed limit for the two solid samples and L1, but are below the limit for L3 samples, in all the sampling periods (due to an experimental error, the $p$-anisidine value for the December sampling was not obtained). The high oxidation values obtained for the solid samples are not totally unexpected, because samples are very rich in PUFA (and thus, extremely prone to oxidation, especially at increased temperatures), and they were collected from the solid residues vessel with a large delay from the time they were deposited in it. It must be kept in mind that those solid residues are those arising from cleaning the fish after the steam cooking (drying) process, and therefore, the temperature of the matrices is superior to room temperature. This event, combined to the exposition to the atmospheric oxygen, may have give rise to an increase in oxidation reactions. Such situation did not occur with liquid samples: L3 samples were collected just after the trays left the steam oven, whereas L1 samples were collected some time later. The abovementioned sampling procedures may justify the high oxidation results obtained, hence defining more strict conditions for sampling procedures, in order to reduce those levels. As already mentioned, the characterization of liquid by-products from fish canning industry is 
extremely scarce, and therefore comparison between the obtained results and literature was not possible.
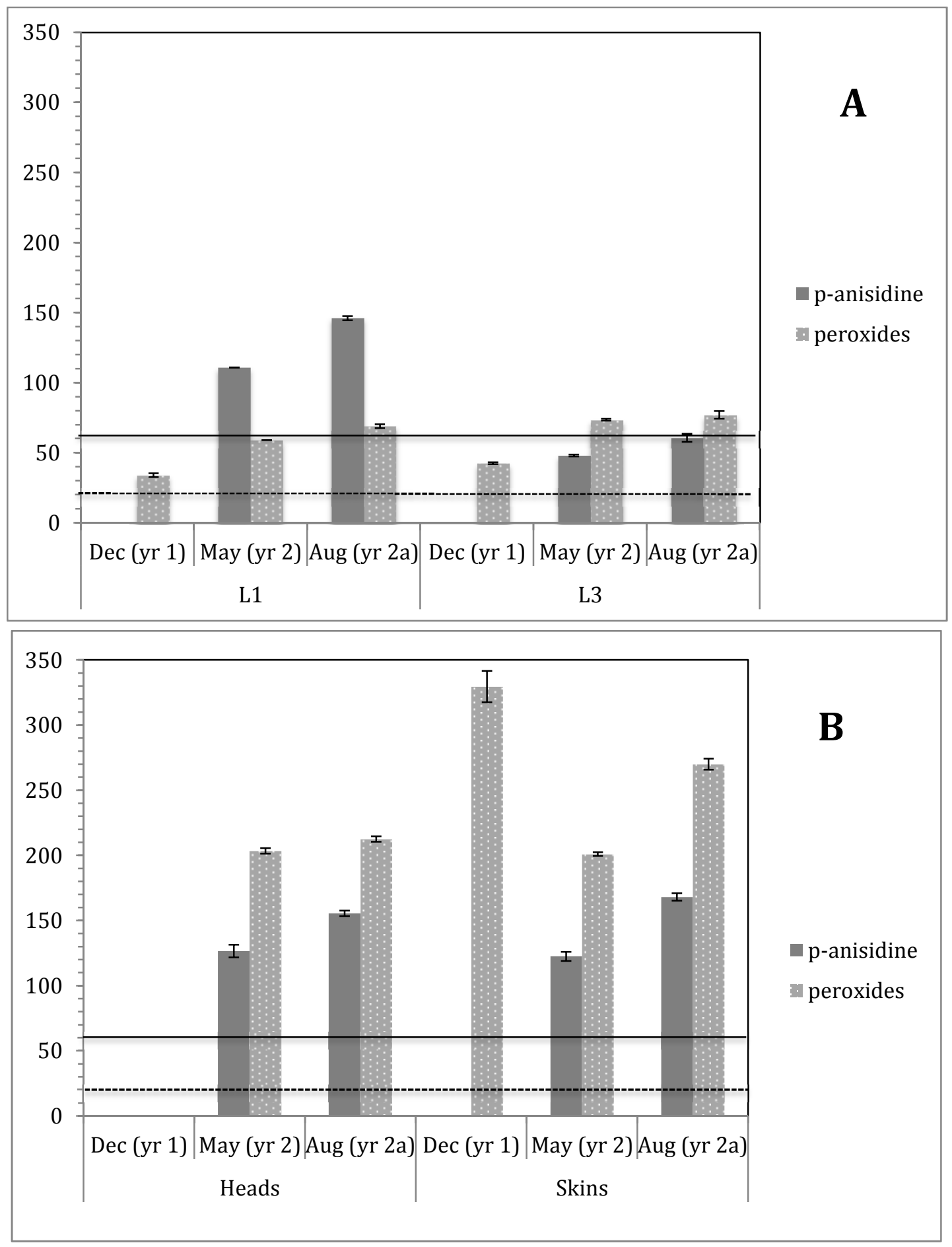
Figure 4 - Oxidation levels, in terms of peroxides and p-anisidine content, in the liquid (A) and solid (B) discards collected along two sampling points of the year (December of year 1 and May of year 2). Values from August of year 2 correspond to the samples collected in May and stored at $-20^{\circ} \mathrm{C}$ for 3 months. Values regarding peroxide are presented in $\mathrm{m}_{\mathrm{eq}} \mathrm{O}_{2} / \mathrm{kg}$ fat. Horizontal lines denote the maximal admissible values for p-anisidine (continuous line) and peroxides (dashed line) content

Microbial counting values are low (between 2.0-3.5 log cfu/g and <1.0-4.4 log cfu/g in solid and liquid discards, respectively) and do not increase after a period of freezing storage (from May to August). However, the storage at freezing temperatures $\left(-20^{\circ} \mathrm{C}\right)$, is economically impractical in industrial environment. Other alternatives of storage at higher temperatures (room temperature or cooling) were also studied, but discarded, because of the high degradation observed after a few days. In conclusion, these by-products should be processed in a relatively short time after collection, so as to be readily converted into concentrated extracts containing the compounds of potential value added; these extracts have a much reduced volume, which already makes it feasible the preservation at low temperatures.

\section{Evaluation of compounds with high-added value}

Based on the analysis previously performed, two by-products with potential for valorisation were selected, in order to evaluate methodologies for extraction and purification of compounds with added value: liquid L3 fraction, and solid fraction (composed of heads and cooked skins). From the abovementioned fractions, two approaches were designed: one integrates the extraction of lipids from L3, rich in $\omega 3$ PUFA, and another integrating the protein fraction, rich in proteins, peptides and soluble amino acids. The overall layout of the processes is depicted in Figure 1. Although here it was decided to work with both fractions separately, another alternative would be to mix solid and liquid fractions, therefore eliminating the need to add water to the former, and thus enhancing the amounts of lipid and proteins obtained in the end of the extraction/purification procedure.

\section{Valorisation of lipid extracts rich in $\omega 3$ PUFA}

Lipid extraction was carried out with hexane, which has a food grade status (Directive $2009 / 32 / E C)^{28}$, a consideration of utmost importance in the present studies, because of the intended food applications of the extracted compounds. Furthermore, it is the conventional technology used in industrial oil extraction processes, since there are no economically reliable 
alternatives yet. Finally, the recovery of ca. $95 \%$ of the initial amount of hexane is possible (unpublished results obtained in our laboratory), since the final part of the process consisted on the evaporation of the solvent under reduced pressure, which was reused in subsequent extraction procedures.

Results of the fatty acid profile of both solid and liquid samples from distinct sampling periods are presented in Table 1. As expected, palmitic (C16:0), oleic (C18:1 $\omega 9)$, eicosapentaenoic

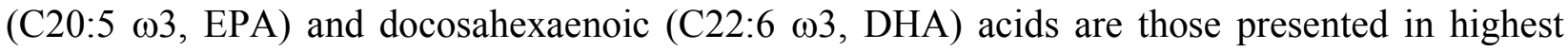
amounts, and both solid and liquid by-products are interesting sources of $\omega 3$ PUFA. Table 1 also presents several nutritional quality indexes of lipids, namely the ratio $\omega 6 / \omega 3$, atherogenic index (AI), thrombogenic index (TI), and ratio of hypocholesterolemic/hypercholesterolemic fatty acids $(\mathrm{HH})$, calculated according to Ulbricht and Southgate. ${ }^{29}$ Since a ratio $\omega 6 / \omega 3$ below 4.0 was proposed as adequate for the prevention of cardiovascular risks, ${ }^{30}$ our solid and liquid by-product fractions present a healthy ratio, as their ratio ranges between $0.05-0.18$. AI and TI indicate if a food is suitable for the prevention of cardiovascular diseases, and should be low in the diet. On the other hand, the $\mathrm{HH}$ index is specifically related to cholesterol metabolism, and thus an index number higher than 2.0 is expected for suitable nutritionally lipids. The relatively low $\mathrm{HH}$ values found in our fractions were due to the negative contribution of $\mathrm{C} 16: 0$, a predominant fatty acid in sardine species. On the other hand, AI and TI values were low, indicating that the studied fractions can be classified as potentially healthy to incorporate in food products. Moussa et al. ${ }^{31}$ found AI and TI values of 1.86 and 0.74 for raw sardine fillets, whereas the $\omega 6 / \omega 3$ ratio was 0.53; Marin et al. ${ }^{22}$ described AI values for Sardina pilchardus fillets between 0.43-0.98, higher than the recommended value (lower than 0.72 ). 
Table 1 - Fatty acid content and lipid nutritional indices of liquid (collected in July and December of year 1, and May of year 2) and solid by-products (collected in

\begin{tabular}{|c|c|c|c|c|c|c|c|c|c|c|}
\hline \multirow{3}{*}{ FA ( $\%$ of total FA) } & \multicolumn{9}{|c|}{ December of year 1 and May of year 2) } & \\
\hline & \multicolumn{2}{|c|}{ Heads } & \multicolumn{2}{|c|}{ Skins } & \multicolumn{3}{|c|}{ L1 } & \multicolumn{3}{|c|}{ L3 } \\
\hline & Dec1 & May2 & Dec1 & May2 & Jul1 & Dec 1 & May2 & Jul1 & Dec1 & May2 \\
\hline \multicolumn{11}{|l|}{ Saturated fatty acids } \\
\hline C14:0 & $6,89 \pm 0,13^{\mathrm{a}}$ & $6,62 \pm 0,23^{\mathrm{a}}$ & $6,80 \pm 0,10^{\mathrm{a}}$ & $8,53 \pm 0,41^{\mathrm{b}}$ & $5,41 \pm 0,07^{\mathrm{c}}$ & $5,20 \pm 0,27^{\mathrm{c}}$ & $5,73 \pm 0,11^{\mathrm{d}}$ & $8,25 \pm 0,10^{\mathrm{b}}$ & $8,34 \pm 0,16^{\mathrm{b}}$ & $8,56 \pm 0,28^{\mathrm{b}}$ \\
\hline $\mathrm{C} 16: 0$ & $25,35 \pm 1,03^{\mathrm{a}}$ & $28,56 \pm 2,11^{\mathrm{abc}}$ & $27,36 \pm 0,28^{\mathrm{b}}$ & $31,04 \pm 2,86^{\mathrm{c}}$ & $33,78 \pm 1,12^{\mathrm{c}}$ & $34,19 \pm 1,03^{\text {cd }}$ & $36,60 \pm 2,03^{\mathrm{cd}}$ & $25,71 \pm 0,78^{\mathrm{a}}$ & $27,05 \pm 1,00^{\mathrm{a}}$ & $30,12 \pm 2,08^{\mathrm{c}}$ \\
\hline $\mathrm{C} 18: 0$ & $5,42 \pm 0,15^{\mathrm{a}}$ & $4,78 \pm 0,08^{\mathrm{b}}$ & $5,20 \pm 0,10^{\mathrm{a}}$ & $6,66 \pm 0,28^{\mathrm{c}}$ & $4,43 \pm 0,29^{b}$ & $8,68 \pm 0,27^{\mathrm{d}}$ & $5,64 \pm 0,11^{\mathrm{a}}$ & $5,40 \pm 0,10^{\mathrm{a}}$ & $7,63 \pm 0,07^{\mathrm{d}}$ & $5,41 \pm 0,14^{\mathrm{a}}$ \\
\hline $\mathrm{C} 20: 0$ & $1,50 \pm 0,02^{\mathrm{a}}$ & $1,56 \pm 0,17^{\mathrm{a}}$ & $0,83 \pm 0,09^{\mathrm{b}}$ & $2,12 \pm 0,15^{\mathrm{c}}$ & $1,30 \pm 0,08^{\mathrm{d}}$ & $0,72 \pm 0,02^{\mathrm{b}}$ & $1,0 \pm 0,05^{\mathrm{b}}$ & $0,93 \pm 0,03^{\mathrm{b}}$ & $0,78 \pm 0,02^{\mathrm{b}}$ & $1,04 \pm 0,05^{\mathrm{b}}$ \\
\hline \multicolumn{11}{|c|}{ Monounsaturated fatty acids } \\
\hline $\mathrm{C} 16: 1(\omega 7)$ & $7,35 \pm 0,23^{\mathrm{a}}$ & $8,62 \pm 0,35^{\mathrm{b}}$ & $8,10 \pm 0,10^{\mathrm{b}}$ & $9,34 \pm 0,39^{\mathrm{c}}$ & $8,76 \pm 0,66^{\mathrm{bc}}$ & $8,28 \pm 1,01^{\mathrm{bc}}$ & $9,22 \pm 0,99^{\mathrm{c}}$ & $7,97 \pm 0,76^{b}$ & $11,04 \pm 1,21^{\mathrm{d}}$ & $8,10 \pm 0,87^{\mathrm{bc}}$ \\
\hline $\mathrm{C} 18: 1(\omega 9)$ & $12,10 \pm 0,73^{\mathrm{a}}$ & $11,31 \pm 0,95^{\mathrm{a}}$ & $16,95 \pm 0,87^{\mathrm{b}}$ & $15,35 \pm 1,01^{\mathrm{c}}$ & $14,41 \pm 0,72^{\text {cd }}$ & $13,23 \pm 0,45^{\mathrm{d}}$ & $12,80 \pm 0,56^{\mathrm{d}}$ & $14,78 \pm 0,66^{\mathrm{c}}$ & $14,13 \pm 1,00^{\text {cd }}$ & $13,75 \pm 0,55^{\circ}$ \\
\hline $\mathrm{C} 20: 1(\omega 9)$ & $1,58 \pm 0,07^{\mathrm{a}}$ & $1,94 \pm 0,14^{\mathrm{b}}$ & $1,59 \pm 0,06^{\mathrm{a}}$ & $1,31 \pm 0,03^{\mathrm{c}}$ & $3,80 \pm 0,28^{\mathrm{d}}$ & $2,40 \pm 0,05^{\mathrm{e}}$ & $3,72 \pm 0,19^{d}$ & $2,81 \pm 0,08^{\mathrm{e}}$ & $1,78 \pm 0,03^{\mathrm{b}}$ & $2,73 \pm 0,05^{\mathrm{e}}$ \\
\hline \multicolumn{11}{|c|}{ Polyunsaturated fatty acids } \\
\hline $\mathrm{C} 18: 2(\omega 6)$ & $1,27 \pm 0,06^{\mathrm{a}}$ & $1,35 \pm 0,05^{\mathrm{ab}}$ & $1,40 \pm 0,08^{\mathrm{b}}$ & $1,25 \pm 0,02^{\mathrm{a}}$ & $1,47 \pm 0,09^{\mathrm{b}}$ & $1,76 \pm 0,06^{\mathrm{c}}$ & $2,33 \pm 0,10^{\mathrm{d}}$ & $2,75 \pm 0,11^{\mathrm{e}}$ & $2,28 \pm 0,10^{\mathrm{d}}$ & $3,35 \pm 0,09^{\mathrm{f}}$ \\
\hline $\mathrm{C} 18: 3(\omega 3)$ & $3,10 \pm 0,11^{\mathrm{a}}$ & $2,60 \pm 0,09^{\mathrm{b}}$ & $4,26 \pm 0,15^{\mathrm{c}}$ & $3,66 \pm 0,17^{\mathrm{d}}$ & $4,05 \pm 0,22^{\mathrm{c}}$ & $4,30 \pm 0,20^{\mathrm{c}}$ & $4,53 \pm 0,17^{\mathrm{c}}$ & $4,00 \pm 0,24^{\text {cd }}$ & $3,36 \pm 0,23^{\mathrm{d}}$ & $3,60 \pm 0,17^{\mathrm{d}}$ \\
\hline $\mathrm{C} 18: 3(\omega 6)$ & nd & nd & nd & nd & nd & nd & nd & nd & nd & nd \\
\hline $\mathrm{C} 18: 4(\omega 3)$ & $2,94 \pm 0,15^{\mathrm{a}}$ & $2,21 \pm 0,09^{\mathrm{b}}$ & $2,40 \pm 0,11^{\mathrm{c}}$ & $2,10 \pm 0,11^{\mathrm{bc}}$ & $2,20 \pm 0,05^{\mathrm{b}}$ & $2,15 \pm 0,13^{\mathrm{b}}$ & $2,11 \pm 0,03^{\mathrm{c}}$ & $3,26 \pm 0,29^{\mathrm{a}}$ & $2,20 \pm 0,08^{\mathrm{b}}$ & $2,79 \pm 0,06^{\mathrm{a}}$ \\
\hline $\mathrm{C} 20: 4(\omega 6)$ & $0,94 \pm 0,02^{\mathrm{a}}$ & $0,36 \pm 0,01^{\mathrm{b}}$ & $0,80 \pm 0,02^{\mathrm{a}}$ & $0,40 \pm 0,02^{\mathrm{b}}$ & $1,81 \pm 0,06^{\mathrm{c}}$ & $0,34 \pm 0,01^{\mathrm{b}}$ & $1,57 \pm 0,08^{\mathrm{c}}$ & $0,58 \pm 0,03^{\mathrm{d}}$ & $0,18 \pm 0,01^{\mathrm{e}}$ & $0,09 \pm 0,00^{\mathrm{f}}$ \\
\hline $\mathrm{C} 20: 5(\omega 3)$ & $13,63 \pm 0,90^{\mathrm{a}}$ & $13,82 \pm 0,56^{\mathrm{a}}$ & $9,25 \pm 0,09^{\mathrm{b}}$ & $9,57 \pm 0,11^{\mathrm{b}}$ & $12,66 \pm 0,23^{\mathrm{a}}$ & $8,30 \pm 0,07^{\mathrm{d}}$ & $7,39 \pm 0,05^{\mathrm{d}}$ & $13,21 \pm 0,06^{\mathrm{a}}$ & $9,60 \pm 0,04^{\mathrm{b}}$ & $8,57 \pm 0,11^{\mathrm{d}}$ \\
\hline $\mathrm{C} 22: 5(\omega 3)$ & $0,60 \pm 0,02^{\mathrm{a}}$ & $0,50 \pm 0,01^{\mathrm{a}}$ & $1,30 \pm 0,08^{\mathrm{b}}$ & $1,25 \pm 0,06^{\mathrm{b}}$ & $0,61 \pm 0,02^{\mathrm{a}}$ & $1,62 \pm 0,04^{\mathrm{c}}$ & $0,83 \pm 0,01^{\mathrm{d}}$ & $1,00 \pm 0,01^{\mathrm{e}}$ & $1,40 \pm 0,03^{\mathrm{b}}$ & $2,00 \pm 0,09^{\mathrm{f}}$ \\
\hline $\mathrm{C} 22: 6(\omega 3)$ & $17,18 \pm 0,75^{\mathrm{a}}$ & $15,70 \pm 0,70^{\mathrm{b}}$ & $13,68 \pm 0,55^{\mathrm{c}}$ & $7,41 \pm 0,12^{\mathrm{d}}$ & $5,20 \pm 0,21^{\mathrm{e}}$ & $9,07 \pm 0,35^{\mathrm{f}}$ & $6,60 \pm 0,40^{\mathrm{e}}$ & $9,25 \pm 0,14^{\mathrm{f}}$ & $10,23 \pm 0,61^{\mathrm{f}}$ & $9,81 \pm 0,54^{\mathrm{f}}$ \\
\hline SUM $\omega 3$ & 37,45 & 34,83 & 30,89 & 23,99 & 24,72 & 25,44 & 21,46 & 30,72 & 26,79 & 26,77 \\
\hline SUM $\omega 6$ & 2,21 & 1,71 & 2,20 & 1,65 & 3,28 & 2,10 & 3,90 & 3,33 & 2,46 & 3,44 \\
\hline$\omega 6 / \omega 3$ & 0,06 & 0,05 & 0,07 & 0,07 & 0,13 & 0,08 & 0,18 & 0,11 & 0,09 & 0,13 \\
\hline AI & 0,87 & 0,94 & 0,91 & 1,26 & 1,01 & 1,07 & 1,16 & 0,98 & 1,07 & 1,17 \\
\hline $\mathrm{TI}$ & 0,27 & 0,29 & 0,32 & 0,46 & 0,45 & 0,47 & 0,57 & 0,34 & 0,41 & 0,43 \\
\hline $\mathrm{HH}$ & 1,61 & 1,36 & 1,46 & 1,04 & 1,08 & 1,04 & 0,90 & 1,44 & 1,23 & 1,14 \\
\hline
\end{tabular}

nd - not detected; different superscript letters in each row denote statistically different results 


\section{Valorisation of protein extracts with anti-hypertensive activity}

When muscle proteins are submitted to hydrolysis, the proportion of small peptides and free amino acids is increased, thus potentially enhancing the bioactivity of the fraction. Thus, the hydrophilic fractions containing protein were hydrolysed, centrifuged, and the separation of liquid fractions by molecular weight was achieved through ultrafiltration, as depicted in Figure 1. Hydrolysis degree was calculated as 7.8\%. Results (at laboratorial scale) generated a yield of $43 \%$ in solids, and $14 \%$ in peptides with $<3 \mathrm{kDa}$, in relation to the initial amount of raw material.

The solid fraction resulting from the first centrifugation was used as protein substitute in food matrices. Specifically, it was incorporated in a fish spread, substituting $10 \%$ of the sardine in the original recipe (which had $60 \%$ of sardine), and the final product was tested and positively evaluated by a small trained sensorial analysis panel. The liquid fraction was evaluated in terms of anti-hypertensive activity (quantified in terms of ACE inhibition). Results regarding this bio-activity describe the $\mathrm{IC}_{50}$ for extracts $\mathrm{ACE}$ as "good" for the fraction F-I (values between $50-150 \mu \mathrm{g} / \mathrm{ml}$, specifically recorded as $109,5 \mu \mathrm{g} / \mathrm{ml}$ ), as well as for fraction F-II (recorded as $51.9 \mu \mathrm{g} / \mathrm{ml}$ ). Other authors described $\mathrm{IC}_{50}$ values of $164 \mu \mathrm{g} / \mathrm{ml}$ for hydrolysates from sardine sarcoplasmic by-products. ${ }^{32}$ These extracts of bioactive peptides offer several advantages, namely their low toxicity, since they are not synthetic. Although health claims are still not allowed regarding bioactive peptides, food market already has products including these ingredients, such as drinks with hydrolysed collagen and hydrolysed milk whey for athletes, and therefore the door is open to introduce more bioactive peptides as functional ingredients in food industry.

The economic viability of producing (at lab scale) the protein substitute (to use in fish spread) and the protein hydrolysate with anti-hypertensive properties was also performed, through the elaboration of a provisional cash flow map, from which the net present value (NPV) and the internal rate of return (IRR) were calculated. Concerning the protein substitute, a NPV of $20.233 €$ and a IRR of $17,8 \%$ allow to conclude that the investment is viable, whereas the production of protein hydrolysate is not economically viable (NPV of -6.785.462€); this negative result is strongly influenced by the cost of the $3000 \mathrm{MWCO}$ filters used, although at pilot or industrial scale other membrane systems would be used, which would decrease production cost and perhaps turn the production economically viable.

In conclusion, constrains related to environmental issues, enforced by legislation, are becoming stringent, making it urgent to develop an optimised system for the utilisation of byproducts generated by food processing industries. Canning fish industry generates by- 
products containing considerable amounts of high-value components, therefore opening the doors to alternative valorisation processes, which may generate value and thus increment boost company competitiveness. According to the results of the present study, liquid byproducts from specific production steps, e.g. from the drying step, could be an interesting source of added-value compounds, as long as a careful management of these fractions is performed, in order to avoid its chemical and/or microbiological deterioration. This procedure could simultaneously reduce the environmental impact of the wastes discarded, and promote a road to obtain extra economic benefits for the company, therefore counterbalancing the obligatory costs related to wastewater treatment before discharge.

\section{Supporting information}

Simplified layout of the processing steps during the canning of sardines, with the correspondent influent and effluent flows for each step. (Adapted from Ferraro et al., 2013)

\section{Synopsis}

The recovery of bioactive compounds from fish canning by-products is a sustainable approach to economically manage effluents and reduce their environmental impact.

\section{Acknowledgements}

This work was supported by project ADI 13634-ValorPeixe, funded by the National Strategic Reference Framework (QREN) and by Fundação para a Ciência e Tecnologia (FCT), and through the project PEst-OE/EQB/LA0016/2013. Authors acknowledge Poveira company for supplying the raw materials. Author Carvalho acknowledges FEDER funds (Norte-01-0145FEDER-000011-RL1-QUALIFOOD).

\section{References}

(1) Lopes, C., Antelo, L.T., Franco-Uría, A., Alonso, A.A. \& Pérez-Martín, R. (2015). Valorisation of fish by-products against waste management treatments - Comparison of environmental impacts. Waste Management, 46, 103-112, DOI 10.1016/j.wasman.2015.08.017

(2) Secci, G., Borgogno, M., Mancini, S., Paci, G. \& Parisi, G. (2017). Mechanical separation process for the value enhancement of Atlantic horse mackerel (Trachurus trachurus), a 
discard fish. Innovative Food Science and Emerging Technologies, 39, 13-18, DOI 10.1016/j.ifset.2016.10.018

(3) Ferraro, V., Carvalho, A.P., Piccirillo, C., Santos, M.M., Castro, P.M. \& Pintado, M.E. (2013). Extraction of high added value biological compounds from sardine, sardine-type fish and mackerel canning residues - A review. Material Science Engineering C, 33, 3111-3120, DOI 10.1016/j.msec.2013.04.003

(4) Etxabide, A., Uranga, J., Guerrero, P. \& Caba $\square$, K. (2017). Development of active gelatin films by means of valorisation of food processing waste: A review. Food Hydrocolloids, 68, 192-198, DOI 10.1016/j.foodhyd.2016.08.021

(5) Ishak, N.H. \& Sarbon, N.M. (2018). A review of protein hydrolysates and bioactive peptides deriving from wastes generated by fish processing. Food and Bioprocess Technology, 11(1), 2-16, DOI 10.1007/s11947-017-1940-1

(6) Terzioğlu, P., Öğüt, H. \& Kalemtaş, A. (2018). Natural calcium phosphates from fish bones and their potential biomedical applications. Materials Science \& Engineering C, 91, 899-911, DOI 10.1016/j.msec.2018.06.010

(7) Arvanitoyannis, I.S. \& Kassaveti, A. (2008). Fish industry waste: treatments, environmental impacts, current and potential uses. International Journal of Food Science and Technology, 43, 726-745, DOI 10.1111/j.1365-2621.2006.01513.x

(8) Horne, R.E. \& Matthews, R. (2004). Biomass-based climate change mitigation through renewable energy (BIOMITRE) Technical Manual. Project NNE5-00069-2002. Retrieved $\begin{array}{llll}\text { August } & 3, & 2018 & \text { from }\end{array}$ http://www.globalbioenergy.org/uploads/media/0411_BIOMITRE_Technical_Manual.pdf

(9) Olsen, R.L., Toppe, J. \& Karunasagar, I. (2014). Challenges and realistic opportunities in the use of by-products from processing of fish and shellfish. Trends in Food Science and Technology, 36, 144-151, DOI 10.1016/j.tifs.2014.01.007

(10) Sousa, S.C., Vázquez, J.A., Pérez-Martín, R.I., Carvalho, A.P. \& Gomes, A. M. (2017). Valorization of by-products from commercial fish species: extraction and chemical properties of skin gelatins. Molecules, 22, 2-12, DOI 10.3390/molecules22091545

(11) Saeli, M., Piccirillo, C., Tobaldi, D.M., Binions, R., Castro, P.M.L. \& Pullar R.C. (2018). A sustainable replacement for $\mathrm{TiO} 2$ in photocatalyst construction materials: hydroxyapatite- 
based photocatalytic additives, made from the valorization of food wastes from marine origin. Journal of Cleaner Production, 193, 115-127, DOI 10.1016/j.jclepro.2018.05.030

(12) ISO Official Method of Analysis $\mathrm{N}^{\circ}$ 973: 1978. International Organization for Standardization.

(13) AOAC. Official Method of Analysis $\mathrm{N}^{\circ} 960.39$ and 997.07 (1990). Assoc. of Official Analytical Chemists, Arlington, VA.

(14) EN 12880:2000 - Characterization of sludges - Determination of dry residue and water content.

(15) NP 3788 (1990). Microbiologia alimentar - Regras gerais para a contagem de bactérias coliformes a $30^{\circ} \mathrm{C}$. Lisboa: IPQ. $7 \mathrm{p}$.

(16) ISO Official Method of Analysis $\mathrm{N}^{\mathrm{o}}$ 3960: 2007. International Organization for Standardization.

(17) AOCS Cd 18-90 (1994). In The Official Methods and Recommended Practices of the American Oil Chemists' Society. AOCS, Champaign, IL.

(18) Haq, M., Ahmed, R., Cho, Y.J. \& Chun, B.S. (2017). Quality properties and biopotentiality of edible oils from Atlantic salmon by-products extracted by supercritical carbon dioxide and conventional methods. Waste Biomass Valor, 8, 1953-1967, DOI $10.1007 / \mathrm{s} 12649-016-9710-2$

(19) Castro-Gómez, P., Fontecha, J., Rodríguez-Alcalá, L.M., (2014). A high-performance direct transmethylation method for total fatty acids assessment in biological and foodstuff samples. Talanta, 128, 518-523, DOI 10.1016/j.talanta.2014.05.051

(20) Tavares, T.G., Contreras, M.M., Amorim, M., Pintado, M.E., I. Recio, I. \& Malcata, F.X. (2011). Novel whey-derived peptides with inhibitory effect against angiotensin-converting enzyme: In vitro effect and stability to gastrointestinal enzymes. Peptides, 32, 1013-1019, DOI 10.1016/j.peptides.2011.02.005

(21) Dumay, J., Allery, M., Donnay-Moreno, C., Barnathan, G., Jaouen, P., Carbonneau, M.E. \& Bergé, J.P. (2009). Optimization of hydrolysis of sardine (Sardina pilchardus) heads with Protamex: Enhancement of lipid and phospholipid extraction. Journal of the Science of Food and Agriculture, 89, 1599-1606, DOI 10.1002/jsfa.3631 
(22) Marin, M., Polak, T., Gašperlin, L. \& Žlender, B. (2010). Variations in the fatty acid composition and nutritional value of Adriatic sardine (Sadina pilchardus) through the fishing season. Acta argiculturae Slovenica, 96/2, 95-101.

(23) Garcia-Sanda, E., Omil, F. \& Lema, J.M. (2003). Clean production in fish canning industries: recovery and reuse of selected wastes. Clean Technology and Environmental Policy, 5, 289-294, DOI 10.1007/s10098-003-0200-4

(24) Batista, I., Ramos, C., Mendonça, R. \& Nunes, M.L. (2009). Enzymatic hydrolysis of sardine (Sardina pilchardus) by-products and lipid recovery. Journal of Aquatic Food Product Technology, 18, 120-134, DOI 10.1080/10498850802581823

(25) Dumay, J., Donnay-Moreno, C., Barnathan, G., Jaouen, P. \& Bergé, J.P. (2006). Improvement of lipid and phospholipid recoveries from sardine (Sardina pilchardus) viscera using industrial proteases. Process Biochemistry, 41, 2327-2332, DOI 10.1016/j.procbio.2006.04.005

(26) EFSA (2010) Scientific Opinion on Fish Oil for Human Consumption. Food hygiene, including Rancidity. EFSA Journal, 8 (10), 1874. Retrieved August 3, 2018 from http://www.efsa.europa.eu/en/efsajournal/pub/1874

(27) Bimbo, A.P. (1998). Guidelines for characterizing food-grade fish oil. Inform, 9, 473483.

(28) Directive 2009/32/EC. Retrieved August 3, 2018 from https://eurlex.europa.eu/LexUriServ/LexUriServ.do?uri=OJ:L:2009:141:0003:0011:EN:PDF

(29) Ulbricht, T.L.V. \& Southgate, D.A.T. (1991). Coronary heart disease: seven dietary factors. The Lancet, 338(19), 985-992.

(30) WHO. (1994). Fats and oils in human nutrition. In: Report of Joint Expert Consultation. Rome, WHO, Food and Agriculture Organization of the United Nations: 147 p. Retrieved August 3, 2018 from http://www.fao.org/docrep/V4700E/V4700E00.htm

(31) Moussa, E-R.W.H., Shereen, A.N., Manal, A., Mehanni, A-H. E. \& Rasha, A.E. (2014). Nutritional value and fatty acid composition of household cooking on fish fatty acids profile using atherogenicity and thrombogenicity indices. Journal of Food Chemistry and Nutrition, 02 (01), 27-41, ISSN: 2307-4124

(32) Vieira, E. F. \& Ferreira, I.M.P.L.V.O. (2017). Antioxidant and antihypertensive hydrolysates obtained from by-products of cannery sardine and brewing industries. 
International Journal of Food Properties, 20(3), 662-673, DOI $10.1080 / 10942912.2016 .1176036$ 